\title{
TRANSFORMATION OF THE HUMAN PROSTATE GLAND IN INTERMEDIATE AND LATE FETAL PERIODS OF DEVELOPMENT
}

\author{
Irina Piatsko, Alexander Usovich \\ Department of Anatomy, Vitebsk State Order of Peoples' Friendship Medical University, \\ Vitebsk, Republic of Belarus
}

\begin{abstract}
The purpose of the study was to determinate the morphometric parameters of epithelial cords, prostatic ducts, acini of the human prostate gland and their lining epithelium, the shape of prostate glands, and muscle tissue in fetal periods of development. Material and Method: The study was performed on 19 prostate glands of male sex fetuses of intermediate and late fetal periods. We used the morphometric method of verification of apoptotic cells on stained histoligical preps using the criteria of apoptosis. Morphometric research included measurements of acini and acinar lumen areas, epithelium height, assessment of shape factors. Results: In the late fetal period compared to the intermediate fetal period the acini area was not increased in 1.1 times $(p=0,004)$, the area of acinar lumens increases by 3.8 times $(p=0.0005)$. Changes in the shape of acinar lumens were detected. Conclusion: An insignificant increase of the specific area of the glandular parenchyma in the organ of transformation of the developing glands occurs mainly due to their canalization. The formation of prostatic ducts was not followed by the increase in their total area and was the result of differentiation epithelial cells and apoptosis. Transformation of prostate glands in the prenatal period occurs in a certain sequence: the formation of epithelial buds, their canalization by apoptosis with formation of epithelial ducts and prostatic ducts, and formation of end pieces of prostate glands from these ducts. Apoptotic bodies were removed from the lumen of the prostatic ducts by extrusion. The design and orientation of the smooth muscle bundles around prostatic ducts and acini do not ensure the evacuation of content of the prostate glands in the fetal period.
\end{abstract}

Key words: apoptosis, canalization, prostate development.

\section{RESUMEN}

Como el objetivo del estudio se ha planteado determinar los parâmetros morfométricos de los cordones epiteliales, los conductos prostáticos, luces de las glándulas finales de la próstata humana y el epitelio de revestimiento, las formas de las glándulas finales de la próstata humana, determinación de la relación entre las glándulas de la próstata y su tejido muscular durante los períodos del desarrollo fetal. Material y métodos. El estudio se ha realizado en 19 próstatas de niños de los períodos fetales medio y tardío. Utilizamos un método morfométrico para verificar las células apoptóticas en especimenes histológicos teñidos utilizando criterios de apoptosis. Los estudios morfométricos incluyeron mediciones del área de las glándulas terminales y sus luces, la altura del epitelio, la evaluación de los factores de forma. Resultados. En el último período de desarrollo fetal, en comparación con el período intermedio del desarrollo fetal, el área de las glándulas finales aumentó 1,1 veces ( $p<0,05)$; el área luminal de de las glándulas finales aumentó 3.8 veces $(p<0.05)$; hubo un cambio en la forma de los luces de las glândulas finales $(p$ $<0.05$ ). Conclusión. Un ligero aumento en el área específica del parénquima glandular en la próstata en desarrollo del feto masculino durante la transformación de las glándulas en desarrollo ocurre principalmente debido a la aparicion de las luces. La formación de conductos prostáticos no há sido acompañada por un aumento en su área total, sino que se ha presentado como el resultado de la diferenciación de las células epiteliales y la apoptosis. La transformación de la próstata en el período prenatal de ontogénesis ocurre en una secuencia determinada: la formación de túbulos epiteliales de los cordones epiteliales, su transformación en conductos prostáticos y la formación de las glândulas finales de la prostata. Los cuerpos apoptóticos se eliminan de la luz de los conductos prostáticos por medio de extrusión. La estructura y la disposición de los haces de músculo liso alrededor de los conductos prostáticos y de las glándulas finales no pueden garantizar la secrecion de su contenido durante la edad fetal.

Palabras clave: apoptosis, glándula prostática, glándulas finales

* Correspondence to: Irina Piatsko.

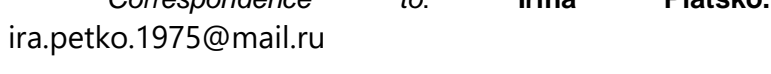

Received: 31 May, 2020. Revised: 18 June, 2020. Accepted: 31 August, 2020. 


\section{INTRODUCTION}

Pathology of the prostate takes a leading place in the structure of diseases in modern men. The results of studies of cell biology, histology, pathological anatomy, clinical observations have explained some causes of prostate disease, including the most common of the benign prostatic hyperplasia (BPH) (Babinski et al., 2003; BrÖssner et al., 2004; Chagas et al, 2002; Toftgard, 2009). However, the multifactorial nature and the lack of established certainty about the etiology and pathogenesis of BPH still necessitates finding answers to these questions. There were suggestions that changes in the prostate in older men are manifestations of developmental disorders of the glands and muscles of the organ in embryonic and fetal periods (Timms and Hofkamp, 2011), and the development of pathological changes in the prostate may be a consequence of the process of impaired organ development (Shapiro, 1990). A closer study of the processes of morphogenesis in the pathologically unchanged prostate can facilitate the understanding of the occurrence of atypical forms of glands and muscle bundles. There were descriptions of metaplasia of the epithelium in the lumen of the forming prostate glands, and prostatic ducts (Ernst et al.,2011), and as the prostate glands mature, such foci become less visible and less common. BruniCardoso and Carvalho (2007) have suggested the formation of lumens in the end pieces of the prostate glands in the rats' fetuses through apoptosis. In connection with the above-stated, we have conducted the study of transformations of the glands and muscles of the prostate from the fetal period to old age, a fragment of which is presented in the article.

Objective: to investigate the formation and transformation of glands and muscle tissue in the human prostate of the fetus.

\section{MATERIALS AND METHODS}

The study was performed on 19 prostates of human fetuses from 14 to 40 weeks of intrauterine growth, which had died from causes not related to reveal gross alterations of the male genitourinary or endocrine system (based on conclusions of protocols of anatomo-pathological researches). The study was performed in accordance with the provisions of the Declaration of Helsinki, and with the law of the Republic of Belarus no. 55-3 "On Burial and Funeral Business", as amended by act no. 2-2235.
The study protocol was approved by the independent Ethics Committee of Vitebsk State Medical University (№2 / 07.05.2018). The information concerning the last menstrual period was considered for the determination of fetal age. Fetus prostates were fixed in $10 \%$ neutral formalin solution. The fixed prostate was cut in the sagittal, frontal, and horizontal planes, embedded in paraffin according to the standard technique. Sections of $5 \mu \mathrm{m}$ thick were prepared with a Leica RM 2125 RT rotary microtome (Germany). Histological sections were stained with hematoxylin - eosin, fuxelin according to Hart. The material was divided into 2 age groups according to embryologic terminology intermediate fetal and late fetal periods [Kolesnikov et al., 2014]. All fetus prostates were examined and photographed under magnification, using the microscope DM 2000 manufactured by Leica and the "Leica D-LUX 3" digital camera (Germany). The micrographs of the prostate glands were processed with the use of the Image Fiji software (Mytsik, 2011; Schneider et al., 2012), using the set of standard tools and plugins. We used the morphometric method of verification of apoptotic cells on stained histoligical preps, using the criteria of apoptosis, as recommended by Skibo and Abramova (2011). Morphometric research included measurements of acini and acinar lumen areas, epithelium height, assessment of shape factors (roundness, Feret diametr) (Mytsik, 2011). Statistical hypothesis was tested using Microsoft Excel 2007 software and Statistica 10.0. The statistical heterogeneity of the samples was tested using nonparametric ANOVA procedures (Kruskal_Wallis test for multiple comparisons). When the statistical heterogeneity of several samples was found, the subsequent identification of heterogeneous groups was performed, using the Mann - Whitney $U$ test and Dunn's post hoc test with the Bonferroni correction. Differences were considered to be significant when $p<0.05$.

\section{RESULTS}

In the prostate of fetus of the intermediate fetal period (14-26 weeks) glandular constructions of different levels of maturity were observed. Round epithelial cords were filled with epithelial cells bounded by a basal membrane. Epithelial tubules had a lumen of different sizes and shapes, and showed no polarization with respect to the basal lamina. In prostatic ducts and acini of the first and second order, the polarization of epithelial cells 
was detected with respect to the basal lamina (Fig. 1).

During this age period, the number of epithelial cords and epithelial tubules dominated over the number of prostatic ducts and the formed glands. The area of epithelial cords was 1.1 times less $(p=0.001)$ of the areas of acini (Table 1$)$. In the late fetal period, in comparison with the intermediate fetal period, the statistically significant change in the size of epithelial cords and prostatic ducts $(p=0.57)$ was not detected. Along with quantitative transformations in the late fetal period, changes in the shape of the glands and their lumen occurred. A sequence of transformation of epithelial cords into the acini in the prenatal period occurs in a specific order, regardless of the age and location of these structures in the developing prostate.

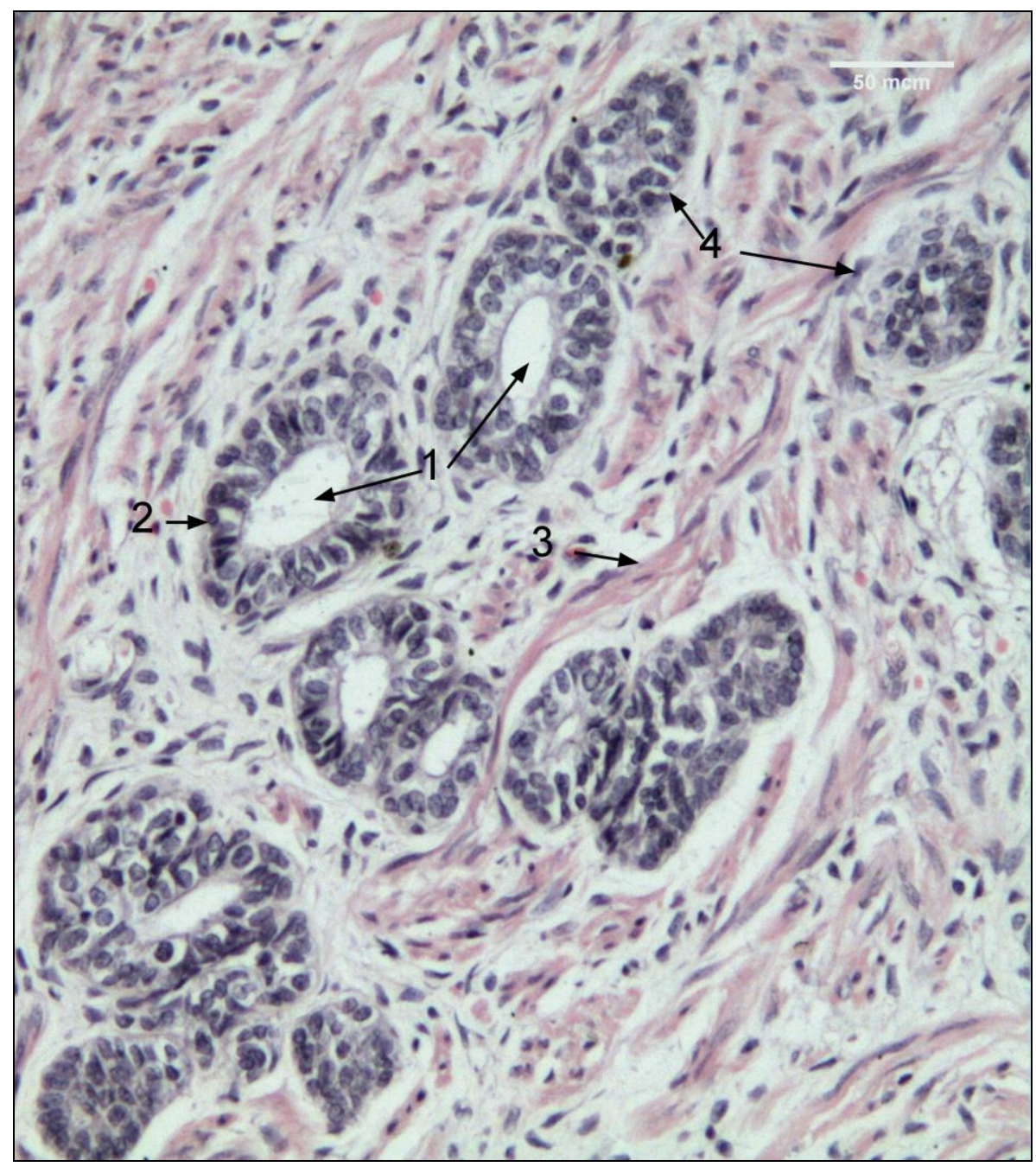

Figure 1- Fetal prostate preparation (week 38). Staining with hematoxylin and eosin. 1. Prostatic ducts. Epithelial cells of the prostatic duct with basally located nuclei 2 . Cell with the signs of karyopyknosis of the nucleus and cleared cytoplasm (apoptotic cells). 3 . Smooth muscle bundles 4 . Epithelial cord with epithelial cells tightly adjoining each other. Epithelial cells contain large nuclei without signs of polarization.

tubules.

Stage 1 - The formation of epithelial

The canalization of epithelial cords was made by apoptosis. It manifested in formation of slit-like gaps within the epithelial cords due to reduction of sizes of individual epithelial cells and loss of intercellular contacts. Transforming epithelial cells had changes in contour: roundness of a cell contour, indentation and protrusion on the cell surface. Nuclei of changed epithelial cells had an uneven contour, a bladed look, in some cases they broke up into micronuclei. Epithelial cords and prostatic tubules were surrounded by single myocytes (Fig 1). 


\begin{tabular}{|l|c|c|}
\hline & Intermediate fetal period & Late fetal period \\
\hline Epithelium height, $\mu \mathrm{m}$ & $12,74(10,1 ; 15,7)$ & $15,5^{*}(12,2 ; 18,9)$ \\
\hline Epithelium cord area, $\mu \mathrm{m}$ & $4244(2981 ; 6758)$ & $4516(3100 ; 7244)$ \\
\hline Acinar area, $\mu \mathrm{m}^{2}$ & $4769(3247 ; 7535)$ & $5967^{*}(4092 ; 9562)$ \\
\hline Acinar lumen area, $\mu \mathrm{m}^{2}$ & $149(95 ; 289)$ & $565^{*}(301 ; 987)$ \\
\hline Roundness of acini & $0,74(0,6 ; 0,8)$ & $0,79(0,6 ; 0,8)$ \\
\hline Roundness of lumens & $0,70(0,5 ; 0,7)$ & $0,64(0,4 ; 0,7)$ \\
\hline Feret diamenr of acini & $105(86 ; 124)$ & $112(84 ; 148)$ \\
\hline Feret diamenr of acinar lumens & $20(14 ; 34)$ & $72^{*}(42 ; 11)$ \\
\hline
\end{tabular}

Table 1- Prostate glad size and factors of shape in intermediate and lateral fetal periods. Results are represented as M (1st Qu; 3rd Qu), where M is median and first Qu and third Qu are the first and third quartiles, respectively

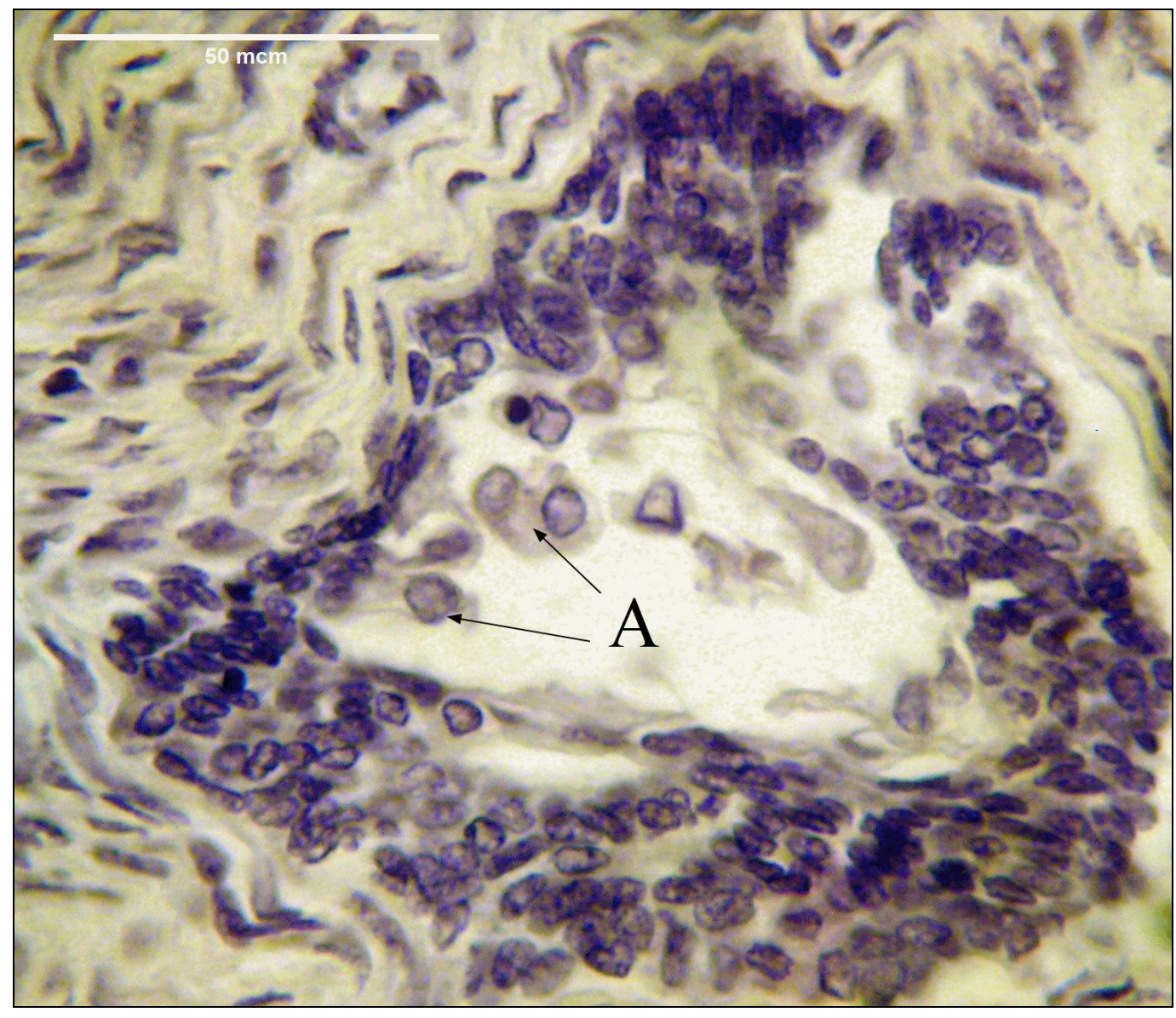

Figure 2- Fetal prostate preparation (week 22). Staining with hematoxylin and eosin. A-conglomerates of apoptotic cells in the prostatic ductal lumens. 
Stage 2 - Formation of prostatic ducts.

Prostatic ducts were formed by canalization of epithelial cords and epithelial tubules. At the same time, their epithelium were reorganized into two different cell populations: basal epithelial cells localized along the basement membrane, represented by cubic epithelial cells, and the inner cell layer, formed by flat or cubic cells. We have found apoptotic bodies throughout the entire prenatal period (Fig. 2) within the emerging prostatic ducts. From 11-12 weeks of fetal development we have observed the initial sings of canalizations of the prostatic ducts. The canalization of the prostatic ducts occurs in direction from the urethra to the acini. Around the prostatic ducts were detected bundles of myocytes, located mainly circularly and longitudinally, but without a visually determined connection with the prostatic ducts.

Stage 3 - Formation and growth of acini. In the early prenatal period, we have identified the formation of acini of the first order at the distal ends of the prostatic ducts. In intermediate and late fetal periods the acini of the second and third order were found. In the intermediate fetal period the part of the glands has a typical prostatealveolar-tubular structure. In the late fetal period, compared to the intermediate fetal period, the acini area was increased in 1.1 times $(p=0.004)$. An insignificant increase of the specific area of the glandular parenchyma in the organ of transformation of the developing glands occurs, mainly, due to their canalization (the area of acinar lumens increases by 3.8 times ( $p$ $=0.0005)$. In the fetal period, changes in the shape of acinar lumens were detected.

In the acini, in the late fetal period, compared with the intermediate fetal period, the secretory epithelium transformed from flat to cubic, and the height of epithelial cells was increased in 1.2 times $(p=0.0000)$. The epithelium lining the acini at this age did not differ from the epithelium of the prostatic ducts. The forming acini were loosely surrounded by multidirectional bundles of smooth myocytes. In areas of glands with formed prostate ducts and forming acini, the number of apoptotic bodies prevailed in the sections of the prostatic ducts closest to the urethra, compared with their sections near the acini.

\section{DISCUSSION}

Our observations were consistent with the results of studies of rat prostate, which also showed that the formation of prostatic epithelial tubules and prostatic ducts was not followed by increase in the area and was the result of differentiation of epithelial cells (Bruni-Cardoso and Carvalho, 2007). We did not agree with the previous assumptions that canalization of epithelial cords was the result of segregation of basal and secretory epithelial cells (Hayward et al., 1996). The signs of canalization of epithelial cords into the prostatic ducts were found in different areas of prostate fetuses, which agreed with BruniCardoso results (Bruni-Cardoso and Carvalho, 2007).

Conglomerates of apoptic cells were observed close to the urethra. This allowed us to assume that they were removed from ducal system by extrusion. The transformation of the prostate glands occurs in a specific sequence: epithelial cords, epithelial tubules, prostatic ducts and end pieces of the prostate glands.

In the prenatal period, the design and orientation of the smooth muscle bundles around prostatic ducts and acini do not ensure the evacuation of content of the prostate glands.

\section{Conflict of interest}

None

\section{Funding}

Self sponsored

\section{Ethical approval}

Obtained from the ethics committee of our university

\section{Informed consent}

Not necessary

\section{Contributions}

IAP: Concepts, design, intellectual content, literature search, manuscript preparation, statistical analysis. AKU: Concepts, design, intellectual content, data analysis, manuscript review, manuscript editing.

\section{REFERENCES}

Babinski MA, Chagas MA, Costa WS, Sampaio FJ. 2003. Prostatic epithelial and luminal area in the transition zone acini: morphometric analysis in normal and hyperplastic human prostate. BJU Int. 92: 592-96.

BrÖssner C, Petritsch K, Fink K, Auprich $M$, Madersbacher S, Adlercreutz H., Rehak $P$, Petritsch P. 2004. Phytoestrogen tissue levels in benign prostatic hyperplasia and prostate cancer and their association with prostatic diseases. Urol. 64: 707-11.

Bruni-Cardoso A, Carvalho HF. 2007. Dynamics of the epithelium during canalization of the rat ventral prostate. Anat. Rec. 290: 1223-32. 
Chagas MA, Babinski MA., Costa WS, Sampaio FJB. 2002. Stromal and acinar components of the transition zone in normal and hyperplastic human prostate. BJU Int 89: 699-702.

Ernst LM, Ruchelli ED, Huff DS. 2011. Color Atlas of Fetal and Neonatal Histology. New York: Springer; $414 \mathrm{p}$.

Hayward SW, Baskin LS, Haughney PC. 1996. Epithelial development in the rat ventral prostate, anterior prostate and seminal vesicle. Acta Anat. 155: 81-93.

Kolesnikov LL, Shevlyuk NN, Erofeeva LM. 2014. Terminologia Embriologica. 2nd Ed. Moscow: Geotar-Media; $417 \mathrm{p}$.

Mytsik AV. 2011. Using the ImageJ program for automatic morphometry in histological studies. Omsk Scientific Herald 2: 187-89.
Shapiro E. 1990. Embriologic development of the prostate. Insights into the etiology and treatment of benign prostatic hyperplasia. Urol Clin North Am. 17: 487-93.

Schneider CA, Rasband WS, Eliceiri KW. 2012. $\mathrm{NIH}$ Image to ImageJ: 25 years of image analysis. Nature Methods 9: 671-75.

Skibo YV, Abramova ZI. 2011. Methods for the study of programmed cell death. Educational and methodological manual for masters at the rate of "Theory of apoptosis" 1st Ed. Kazan: FGAOU VPO KFU; $\mathrm{p} 61$.

Timms BG, Hofkamp LE. 2011. Prostate development and growth in benign prostatic hyperplasia. Differentiation 82: 173-83.

Toftgard R. 2009. Two sides to cilia in cancer. Nat Med. 15: 994-96. 